Mineurs en migration : enjeux juridiques, politiques et sociaux

\title{
Protecting Asylum Seeking Children on the Move
}

La protection des mineurs migrants non accompagnés demandeurs d'asile Proteger a los menores solicitantes de asilo en situación de migración independiente

\section{Ravi KS Kohli}

\section{(2) OpenEdition \\ 12 Journals}

\section{Electronic version}

URL: https://journals.openedition.org/remi/6768

DOI: $10.4000 /$ remi.6768

ISSN: $1777-5418$

\section{Publisher}

Université de Poitiers

\section{Printed version}

Date of publication: 1 March 2014

Number of pages: 83-104

ISBN: 979-10-90426-21-4

ISSN: 0765-0752

\section{Electronic reference}

Ravi KS Kohli, "Protecting Asylum Seeking Children on the Move", Revue européenne des migrations internationales [Online], vol. $30-\mathrm{n}^{\circ} 1$ | 2014, Online since 01 March 2017, connection on 14 April 2022. URL: http://journals.openedition.org/remi/6768 ; DOI: https://doi.org/10.4000/remi.6768 


\title{
Protecting Asylum Seeking Children on the Move
}

\section{Ravi KS Kohli ${ }^{1}$}

\author{
"I am the one \\ Who always goes \\ Away with my home
}

Which can only stay inside in my blood - my home which does not fit

With any geography" (Bhatt, 1997).

\section{Introduction ${ }^{2}$}

Movement is part of life and living on. For children who are seeking asylum in countries that they hope will protect them, being on the move brings challenges and opportunities, risks and danger, where many others make decisions about them, as they decide for themselves how to go on, and how to be still, in the contexts and processes that surround them. Their movements from danger to safety are part of greater migratory flows that generate life, death, and uncertainty depending on the contexts of reception, resettlement or return. The stanza by Sujata Bhatt above, within a larger poem called The One Who Goes Away, exemplifies the ways that children seeking asylum ${ }^{3}$, like all migrants, can locate and dislocate themselves when they move. They simultaneously integrate and disintegrate during shifts from one place to another, as they carry their worlds with them into new worlds. In emphasising the atomised nature of moving away from the earth where you were rooted, it evokes the ways in which children who have experienced forced migration make sense of their lives, for themselves and for others, and how others need to understand the worlds they carry, and the worlds they live in.

\footnotetext{
1 Professor of Child Welfare, University of Bedfordshire, Park Square, Luton, Bedfordshire, LU1 3JU, UK; ravi.kohli@beds.ac.uk

2 This paper is based on a lecture given in October 2012 at a conference hosted by Université de Poitiers (2012) Les mineurs non accompagnés et sans protection en Europe, [online]. URL: http://uptv.univ-poitiers.fr/program/les-mineurs-non-accompagneset-sans-protection-en-europe/index.html

3 The term "asylum seeking children" in this instance refers to those who make formal asylum applications in their own right in countries such as the UK. They are part of a broader group of "separated children" - that is, those who appear in different European countries as lone children seeking protection, without resorting to an asylum application.
} 
In this paper, in reference to existing research as well as broader literary works, I explore the notion that children seeking asylum move in three dimensions at the same time. Firstly, they make journeys across geographical spaces, beyond the borders of the country of origin, to get to safety. Secondly, they also move across time, getting older as they go, amassing experiences and memories of where they have been. They place these alongside their hopes for a future that is sustaining. Thirdly, they move psychologically in different directions, adjusting their experiences like gyroscopes seeking balance, arranging their stories of who they are, what happened to them, and how they came to be asking for asylum. These movements in inner and outer worlds require energy and will in order to feel coordinated and harmonised, and to settle in a country where protection is present legally, practically and psychologically in the short and long term. Yet the management of these movements is seldom possible without the orchestrated commitment of helpers, whose ethics, skills and expert knowledge need to be deployed carefully to assist children on the move. The purpose of assistance is in itself, in broad terms, about ensuring such children can generate a sense of being "at home" in safe and durable ways wherever they are located in countries of lifelong settlement. So, in considering how the fluid nature of their circumstances can be given some solid hope, this article considers the following three related aspects:

- Movement in the lives of children seeking asylum. Here, within a broader landscape of migration, I consider displacement, the passage of time and maturational and psychological transitions as three dimensions along which children move.

- Protection and its meaning in legal, practical and psychological frames.

- "Home" and its meaning to young asylum seekers in reference to a Guardianship Service in Scotland, that has attempted to understand movement and protection in offering a sustaining response to children in contingent circumstances.

\section{Movement and Migration}

To understand the lives and trajectories of children seeking asylum in richer nations, it is first necessary to reflect on the contexts they are coming from, and the ones they are going to. Forced migration is happening in the context of much bigger migrations across the globe. In a fast moving world, migration across national boundaries is ever-present, and movement is everywhere (Urry, 2007; Castles, 2013). In its own way it is a form of human global warming that is arguably irreversible. Its consequences leave deep traces on everyday life for those who move, and those who receive them, generating what Vertovec refers to as "super-diversity":

"'Super-diversity' is distinguished by a dynamic interplay of variables, including: country of origin (comprising a variety of possible subset traits such as ethnicity,

language[s], religious tradition, regional and local identities, cultural values and practices), migration channel (often related to highly gendered flows, specific social networks and particular labour market niches), and legal status (including myriad categories determining a hierarchy of entitlements and restrictions)" (Vertovec, 2007: 3).

Migration, within the terms of this definition, challenges and changes the boundaries between migrants and citizens, testing what the word "we" means. The word itself, which may have remained relatively solid for generations, is 
melting, and its definitional borders are diffused, sometimes at great speed in contexts of diversity, and sometimes more slowly when relatively stable and homogenous communities face the prospect of looking around, or looking to the past or future. This turning of the word "we" from solid to liquid has created its own melt-water, now flowing around the landmass of certainties that once gave it a particular and distinctive morphology. Around communities that were once bound by a common identity based on location, now there are communities bound by shared experiences. Through chance, choice or necessity, there is a constant expansion and re-drawing of the borders of the reachable world, and therefore the word "we". As a consequence of its increasingly mobile features, questions of who we are (and therefore the question of who they are, and how "we" respond to "them") require some thoughtful attention, not least because of the dangers of giving black and white responses when faced with the colours of diversity in daily life.

Among a range of powerful feelings that migration generates, there is fear, sadness and exhilaration, anger, and hope, depending on individual and collective biographies and experiences. Those that leave, and those that receive meet together in territories where such feeling mingle, and where there is an increasing awareness of the loss and gain of movements across borders, depending on one's place and position in the territory. Both leavers and receivers may experience, for example, that the once long tail of tradition is getting shorter, because the past is increasingly occluded or lost through lack of repetition, as the tempo and diversity of migratory movement increases. Here, in such contexts, at such times, volume of change added to velocity of transformation creates noise and heat, and it is difficult to distinguish between evolution and mutation. Only some mutations will be sustained, others will fail and fall. Even if the artefacts of tradition are carried across by one generation, (through faith and food, for example) the next generation mutates, and the defining feature of "tradition" that is 'sameness over time' is no longer the same. On each side, a perceived loss of tradition, and therefore the DNA of what makes us who "we" are, creates fractures of identity. People feel exiled from their past. These fractures are managed in different ways. Some are done through bridge building, generating alliances, and paying close attention to the cross-pollination that is necessary across diverse communities in order to feel alive, and not alone. Others are done through isolationism in migrant communities or through host communities' affirmation of greater border controls, the rise of bureaucratised practices of policing, indexing, labelling, and judging those who seek to migrate. In other words, the responses to diversity are in themselves diverse, each giving a different answer to the vexing question of how "we" stay intact and alive, and of how to ensure our sustainable future. It is into this context that refugee children step forward, having given up their past in order to have a future. It is their particular, intricate movement towards life that I consider next.

\section{Movement for Children Seeking Asylum}

Seeking asylum is a fact of life for many millions of the world's children. However, comparatively few of them make it to richer nations. At the end of 2012 there were 10.5 million refugees worldwide under the mandate of the UN High Commission for Refugees (UNHCR, 2013a), with another 4.9 million Palestinian 
refugees registered by the UN Relief and Works Agency (UNWAR) - a total of 15.4 million people. More than half $(55 \%)$ of all refugees worldwide came from five countries: Afghanistan, Somalia, Iraq, Syria, and Sudan. At present, on average, one in four refugees in the world are from Afghanistan, with $95 \%$ of them located in Pakistan and Iran. In 2012 those under the age of eighteen years made up $46 \%$ of the refugee population. About 21,300 asylum applications were lodged by unaccompanied or separated children in seventy-two countries in that year, mostly by Afghani and Somali children. It was the highest number on record since UNHCR started collecting such data in 2006. This compares to 17,700 asylum applications that were lodged by children in sixty-nine countries in 2011. Since 2006, according to UNHCR, at least 113,000 unaccompanied or separated children have lodged asylum claims. In 2012 in Europe, Sweden and Germany registered the largest number of asylum claims by children, 3,600 and 2,100 respectively. Austria and the United Kingdom were third and fourth, with 1,600 and 1,200 unaccompanied asylum seeking children (UASC) claims respectively. UNHCR reports that internationally 5,400 unaccompanied or separated children were recognized in 2012 as refugees or granted a complementary form of protection (UNHCR, 2013).

These figures present a sea of movement, yet cannot show the day-to-day lives of unaccompanied children seeking to get by in transit and destination countries. In the steady reckoning by UNHCR, there are a few biographies or anecdotes to make them palpable, but largely they remain counted en masse rather than understood in terms of their distinct and personal trajectories. And yet, among the many differences that exist in the lives of such children, there is a common theme. This is, that in becoming forced migrants and refugees, they experience the death of everyday life. So the challenges that lie around them are about how to resurrect the commonplace habits, customs, and rhythms of living. In this respect, protection is not simply a matter of being safe through obtaining refugee or some other form of enduring status within the codifications of the country of asylum or settlement, it is also about moving to re-building their lives, by using the scaffolding provided by others, as well as their own capabilities. We can consider their movements in relation to figure 1 on the right ${ }^{4}$.

Movement happens in three dimensions at different speeds - across geographies, over time, and in maturational and psychological transitions. All these movements are inter-dependent and require the management of dangers and risks, and the calibration of protective actions by children and their helpers as they co-construct worlds that are sustainable. As Kohli and Connolly have noted:

"In understanding forced migration, a simple proposition can be used in relation to the change and transition. Change is what happens to you - you become an asylum seeker or refugee because you have to, as the choices that you make are constrained as you flee

from disaster. Transitions are ways in which you make sense of what has happened to you. Change therefore is external, situational, event based and defined by outcome. It can happen quickly. Transitions in contrast are internal, psychological, based on experience, defined in terms of processes, and always take time" (Kohli and Connolly, 2009: 75).

4 Figure 1 is the result of a collaboration between myself and Tamzin Brown of the Principles to Practice Project, based in London, UK, examining the ways that lawyers and others work with children claiming asylum. 


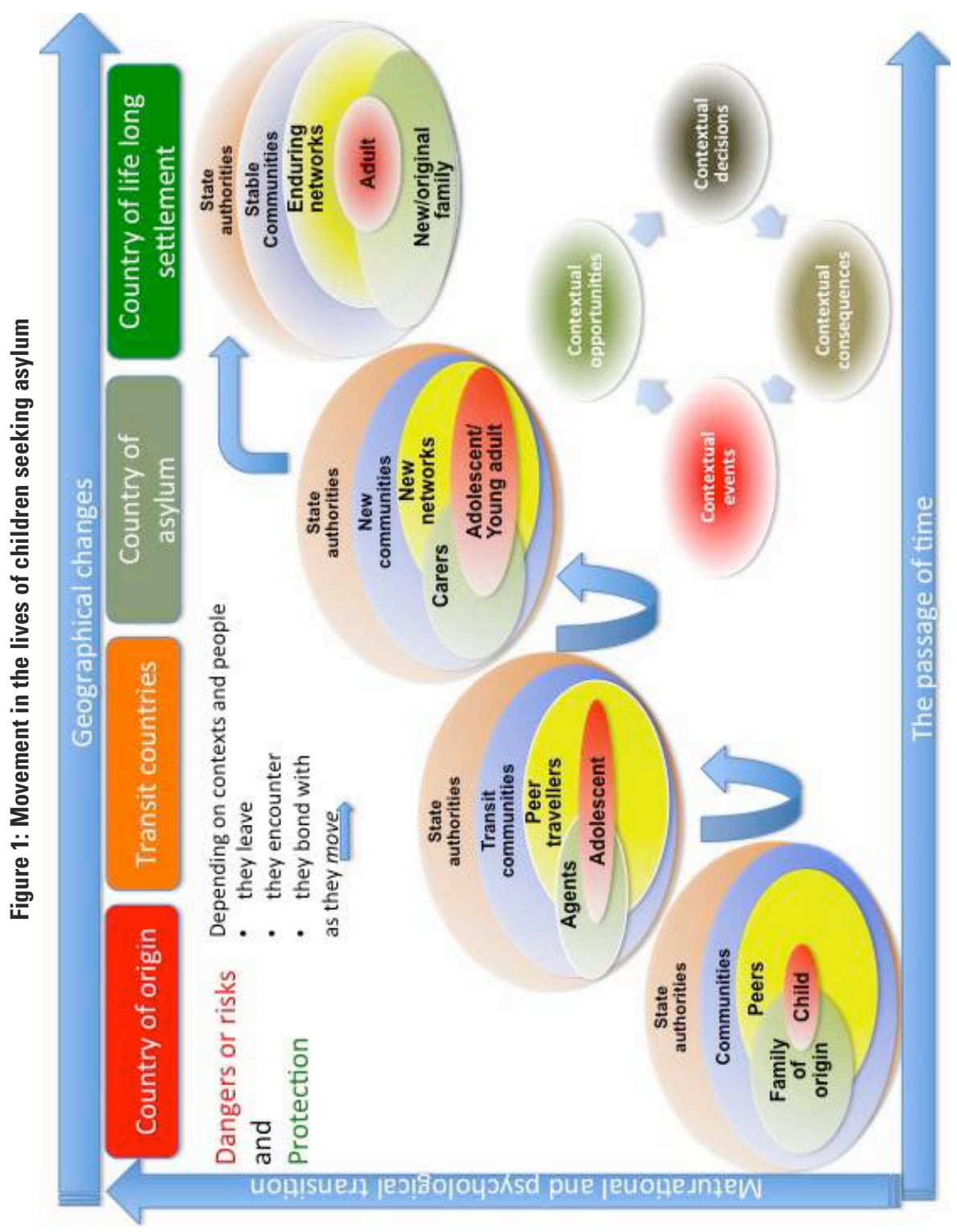


As is well established in the literature on children and forced migration (see, for example, Ayotte, 2000; Bhabha, 2006; Mougne, 2010) geographical changes happen as children move within and then beyond the country of origin towards countries of transit, followed by an asylum application in a destination country, and then towards a country of lifelong settlement. In the country of origin, families may make careful calculations about the child's trajectory, based on perceived benefits of moving. In some respects, when dangers arise in contexts of origin, parents may take a calculated gamble in trying to preserve life (and life chances) for children, with the hope that as their children are cast like dice across the globe, that a double six will turn up for them in the destination country, allowing permanent resettlement. A recurrent relationship is set up between events, opportunities, decisions and their consequences in each phase of the movement away from harm and towards sanctuary. Anticipating risks in relation to patterns or incidents of harmful events in the country of origin, generating planned or improvised opportunities to escape, travel, and arrive, making decisions or living by the decisions made by others, and absorbing the immediate and longer term consequences of such calibrations to stay alive, become part and parcel of life on the move. Children live with these, and moderate them in reference to those they have left behind, those that they encounter on their journeys, and those with whom they bond over time.

As Christiansen and Foighel (1990) observe, there is a profound and enduring complexity related to each aspect of these inter-connections. They argue that movement based on parental protection practices generates a paradox, not least in a context where it may result in permanent loss of contact with family members - a sense of "we love you enough to send you away to somewhere we don't know and have not been, so that you can be safe. But it may mean that we never meet again". This paradox may be compounded by children feeling guilty at moving away from the dangers to which the family remains exposed, to feeling honoured and punished as a carrier of hope of the family, and experiencing deep pressure as the bearers of an economic investment in the family's future. Anderson (2001) observes that these experiences create varying levels of complexity for each child, depending on his or her capabilities and circumstances. The departure to another country far away is, in a sense, an attempt to cut a Gordian knot, literally "to get out of a difficult position by one decisive step; to resolve a situation by force or by evasive action" (Kirkpatrick, 1992). Such desperate acts of protection may form the pulse of movement away from the homeland and the creation of new social worlds and identities.

Balances and bargains are struck with a number of players, depending on those they move away from, who they travel with, and who they encounter across a number of shifting landscapes and territories (Crawley, 2010). Family life in the country of origin is replaced by dependence on agents, and peers who happen to travel with them replace friends. In the destination country, if they reach it, carers replace agents and new acquaintances and friendships are established, even within temporary circumstances. Little is yet known of the ways in which young people fare as they grow into adulthood within a country of life-long settlement, particularly if their asylum claims in the destination country have failed and they are in effect deported (see Refugee Studies Centre, 2013). What is established is that from their genesis to their resolutions, such intrepid and secretive movement across borders and boundaries involve elements of 
luck and planning (Robinson and Segrott, 2002). Here, entitlement and credibility are continually tested, not just at the borders between countries, but also at the boundaries of entering informal and formal networks of care and protection, and in keeping out of harm's way.

Secondly, movement happens across time. Within this time dimension, there is of course, the irreversible experience of chronological time passing in a linear way, connecting one event to the next in sequences that can be re-told. A linear account of time becomes a significant component of the ways asylum seekers' (including children's) stories of persecution, transit and rescue are given credibility by asylum adjudicators (UNHCR, 2013b). The story needs to be clear, coherent, and continuous to be convincing. Fractures in the time line, muddles and lapses, gaps of accounting for when things happened, can lead to breaches of credibility of claim (Herlihy et al., 2002; Bögner et al., 2007). In these circumstances, time is "a race" as well as "a dance" within which forward movements need to be coordinated with good timing in order to succeed (Wong, 2009). Time may have been spent expansively in early childhood in the country of origin, with rhythms of living established over years. Crises leading to departure may have accrued over long periods, or may have happened suddenly and explosively. In transit countries, children may have worked their passages from one point to another, taking time and making time to gather enough resources to move on, waiting for connections, getting intermittent assistance from Non-Governmental Organisations (NGOs) and charities, and gleaning intelligence about routes to destination countries (Senovilla, 2013). On arrival in destination countries, time is marshalled, as their administrative identities of asylum seeker, welfare applicant, school age child, refugee, "unaccompanied", "age disputed", and "trafficked" dominate within more diffused social categorisations of "victim", "bogus migrant", "foreigner", and so on. In part, time is segmented, with appointments for claim determination, seeking legal assistance, or appointments with social workers, doctors, and teachers. Time takes on a peculiar order, as I have noted elsewhere, where they focus on "the present first, the future next, and the past last" (Kohli and Mather, 2003: 208), meeting the need for practicalities, before being able to look forward or to look back.

As time moves in the country of asylum, children get older and advance towards adulthood, and life takes on new patterns and rhythms, away from childhood in the country of origin, and also from the lottery and chaos of lives in transition countries. Here, some specific challenges emerge in the management of time. Long periods of doing nothing at all are punctuated with short bursts of asylum application activities, within which time is elongated and compacted according to the tempo and pace of the asylum claim. Moments, hours, days, weeks and years can be spent consuming time, and watching time. Each portion of time is context dependent, so that moments are sometimes slow, and years go by very speedily as adulthood approaches. In some respects, this is an experience of purgatory, and waiting in limbo, where the road to a secure future is full of diversions and traffic lights, as they become part of a queue of applicants looking at a horizon. As one young person notes, rather poignantly in a recent report on the impact of waiting on young asylum seekers, there is a need in such circumstances to "have a full life not this half life" (Brighter Futures, 2013: 15). As reported by Kohli and Connolly (2009) young people in such circumstances want time to stand still, and simultaneously for it to move on, sometimes gene- 
rating intense traps of feelings where no type of movement of time fits their own tempo of living safely.

In the meantime, maturation and psychological transitions emerge as the third dimension of movement as children seeking asylum grow up and grow older and start to consider what lies beyond the horizon of their claim for political sanctuary. They travel backwards to memories and forwards to hopes and plans, weaving their biographies into forms that allow some sense of what has happened to them, what is happening, and what could happen. This dimension of movement by its nature cannot be wholly linear, or circular. Its path is wayward. Within it there is a balancing of tradition with innovation as they seek to settle, even temporarily into their new country. The raw challenges that face them, having left family behind, are about ways in which the past can be honoured while new ways of making life emerge. They have to balance how they choose to remember with their need to forget some things, in order to carry on. Not every door and window to the past can remain open. They have to consider the terms of how and when to be visible to whom as people who wish to have a life beyond the simple narratives of the asylum story. In doing so children have to find contexts of safe invisibility, akin to other citizens in their new territories. Privacy, confidentiality and secrecy need to be understood in terms of their overlaps and distinctiveness. And it is in such times that stories are gathered, encoded, stored, ignored, edited, segmented, serialised, told and retold, subverted, sentimentalised, believed and disbelieved, in order to move in ways that are generative of political sanctuary. As Nin reminds us, there is a very human aspect to this delicate set of movements:

"We do not grow absolutely, chronologically. We grow sometimes in one dimension, and not in another; unevenly. We grow partially. We are relative. We are mature in one realm, childish in another. The past, present, and future mingle and pull us backward, forward, or fix us in the present. We are made up of layers, cells, constellations" Nin

(1971: 127).

The constellations that children seeking asylum use to guide such movements include trustworthy others who act like moorings among the tides that threaten them. They map out helpers, and navigate their ways forward. Recovery of ordinary life is something that they learn to make happen, rather than something that happens to them. In that respect a successful transition to ordinary life is seldom accidental. It is sometimes planned and orchestrated, and at other times opportunistic and improvised. Even in contexts of transience, where they are in effect continually un-located, they attempt, layer by layer, piece by piece, to do what Bauman (1996) refers to as dissolving into place, in establishing a new mosaic of life. Their capacities to do so are profoundly influenced by those whose actions offer some protection, mitigating the risks that they bring, or the risks they face in the country of asylum, or in a country of future settlement. Protection has many facets. It is both the scaffolding for and the growth of ordinary living, containing legal actions and practical and psycho-social assistance. Through negotiating the production of protection with others, they sense that recovery of ordinary life is possible. 


\section{Protection as a Shield and an Embrace}

When helpers calculate the presence or (more often the absence) of legal, practical and psychological safety in the lives of children seeking asylum, "protection" is a term used widely. It has a history rooted in law (Bhabha and Finch, 2006; Bolton, 2012), social work (Wade et al., 2005; Kohli, 2007) and mental health (Bronstein and Montgomery, 2011), education (Franks, 2006), in the complexities of age assessments (Kvittingen, 2010), therapeutic discourses (Melzak, 1995), in foster care (Wade et al., 2012), identity maintenance (Sporton and Valentine, 2007), the creation of refugee art and poetry (COSTI and UNHCR, 2011), and in recording what children say about their lives and circumstances as forced migrants, including relationships with God (Ojalehto and Wang, 2008; Ni Raghallaigh and Gilligan, 2010). Protection is also considered for those children who are undocumented (Sigona and Hughes, 2012) and trafficked (Rigby and Whyte, 2013). Across such wide fields of study and interest, commentators compact and stretch the definition to give narrow and precise as well as capacious interpretations of protection. These definitions overlap and intermingle, but generally tend to show the miserable consequences for children as forced migrants living in foreign soil. Across this span of writing, the narratives are simple, even if their design is complex. They calculate the arithmetic of suffering. They measure and signal concerns with precision. Then from perspectives often rooted in moral humanitarianism, they argue for justice within the scope of laws, policies, resources and practices that ask others to be like them in searching for fair and sustainable solutions for children seeking asylum. In contexts of ambivalence and hostility towards asylum seekers, they seek reparation, with protection at the core of their varied considerations. As such, these studies form just one thread in a tapestry of opinions about how "we" should respond to "them" for now, and in the future, within broader debates about who needs protecting from whom (Coole, 2002; Louis et al., 2007; Coenders et al., 2013).

Goodwin-Gill (1995: 406), a proponent of both precise and capacious definitions of protection observes that in refugee discourse "'protection' is a term of art, whose meanings are not always clear". It has an exact and immediate definition in terms of security of legal status, as well as a longer, more diffused meaning in relation to caring for children who have sought asylum or are refugees in a lifelong, capacious way. Through its various permutations across legal, welfare and social landscapes, it appears both as a shield and as an embrace over time. At its core, protection is manifest as a shield against persecution, as exemplified in the 1951 Convention relating to the Status of Refugees and extended in its application by the 1967 Protocol relating to the Status of Refugees. The Refugee Convention itself is age-neutral. It makes no mention of children (Pobjoy, 2013). Nonetheless, as for adults making asylum applications, it is used to judge and control children as they move along the line of a refugee determination process. Among others, Guy Goodwin-Gill has long been of the view that this straight line offered by the Refugee Convention needs to be redrawn as a circle when considering enduring protection for children, in terms of its scope and application (see Goodwin-Gill, 2012). His case is that the Convention on the Rights of the Child 1989 can and should extend the scope of protection for children in an embracing way. Specifically Goodwin-Gill states that: 
“The 1989 Convention on the Rights of the Child is rightly recognized as central to the legal protection of children, but protection is not just a narrow question of rights and process; rather, it extends also to the broad range of developmental needs for example, freedom from hunger, rehabilitative care for those who have suffered torture and other

trauma, access to education, and participation in social and cultural life. The CRC uniquely embraces the whole spectrum of children's rights, specifically endorsing the basic principle of the best interests of the child in a total regime oriented to his or her development and self-fulfilment" (Goodwin-Gill, 1995: 410).

The essence of this thinking is also captured in the UN Committee on the Rights of the Child General Comment 14, paragraph 71 that confirms:

"When assessing and determining the best interests of a child or children in general, the obligation of the State to ensure the child such protection and care as is necessary for his or her well-being [...] should be taken into consideration. The terms 'protection and care' must also be read in a broad sense, since their objective is not stated in limited or negative terms (such as 'to protect the child from harm'), but rather in relation to the comprehensive ideal of ensuring the child's 'well-being' and development. Children's wellbeing, in a broad sense includes their basic material, physical, educational, and emotional needs, as well as needs for affection and safety" (UN Committee on the Rights of the

Child, 2013: 15).

These two contributions move in unison to distil some important considerations. Firstly, there is the consideration of taking a whole life perspective on the child who will need to grow up safely in a context where they can fulfil their talents and ambitions. In this instance protection is not a single act at a specific time, but a series on inter-linked actions over an extended period, allowing the child's trajectory to be planned in order to achieve stability into adulthood and older age. This reinforces the precept that protection is more than a guarantee of the absence of immediate harm. It is also the presence of opportunity over time. Secondly, protection is expansive, beyond the determination of a child's asylum status. It includes the provision of welfare, and the regeneration of social networks within which children can re-root. In other words, it has a labile meaning across three domains within which their lives flow, as illustrated in figure 2 on the right.

The UNCRC, in its containment of the fluid meanings of protection, reaches across the domains of asylum, welfare and social networks, because children live across these domains simultaneously, moving around them as they join up their lives, as stated above. The domains themselves vary, from the heavy and hard end of tussles between a child's representatives and asylum decision makers to determine immigration status, to the diffused and delicate aspects of social and cultural collaborations leading to integration. Together, these domains offer both movements and restrictions of movement, in terms of the contested spaces that exist at three levels: firstly, at socio-political levels in the form of authorities that govern their access to legal and practical resources; secondly, at interpersonal levels in their interactions with others; thirdly as a consequence, at intra-psychic levels for each child having to make some sense of why people say yes or no to them when they ask for assistance. This results in the type of churning movement that Papadopoulos (2010: 5) refers to as "disturbance of the 'psycho-ecological settledness', associated with a 'loss of ability to read 


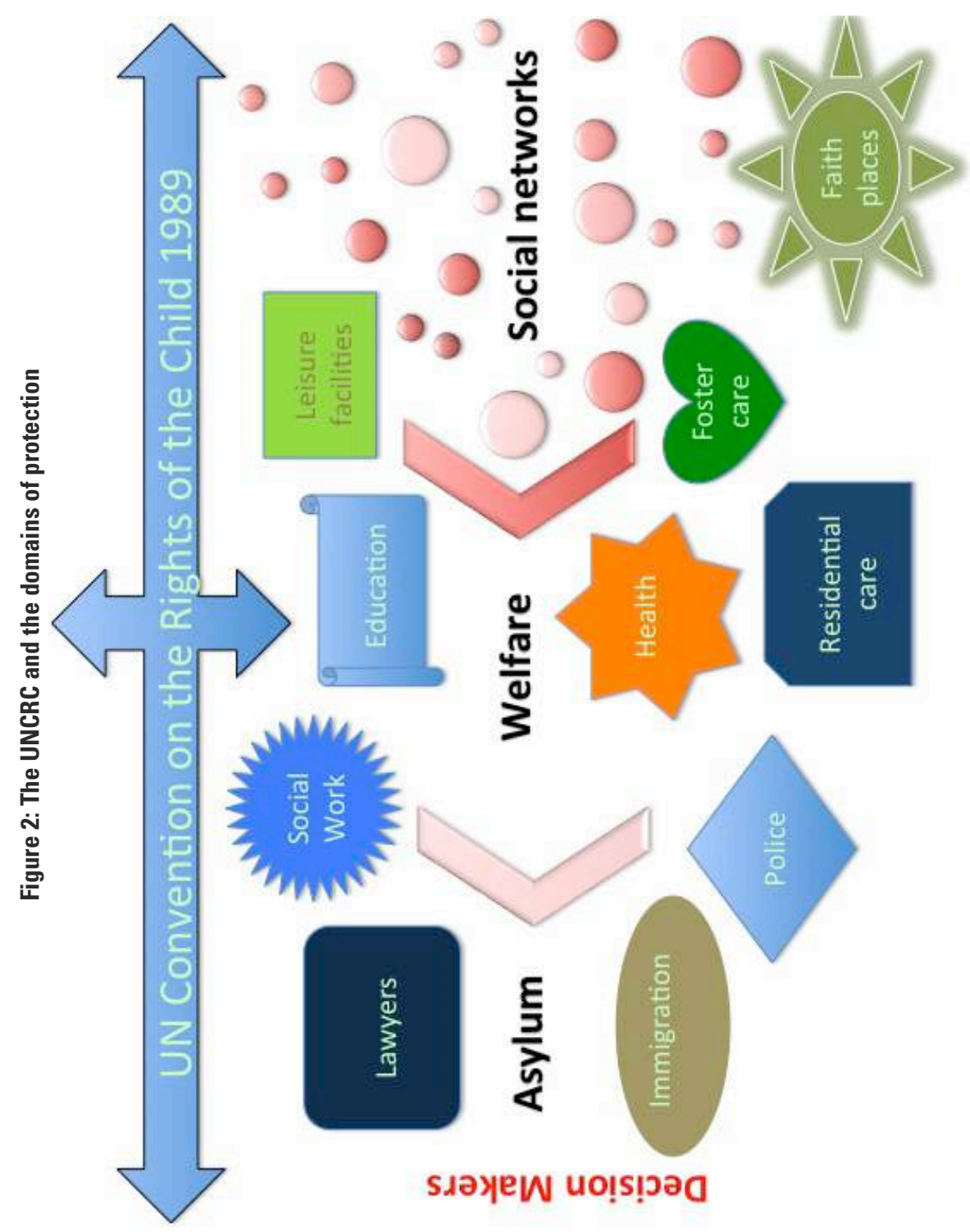


life': inexplicable gap, sense of unreality, unsafety, unpredictability, lack of familiarity, lack of confidence, pervasive anxiety, disorientation, frozenness" (Papadopoulos, 2010: 7).

So the question then arises, about how to make the UNCRC's promises of protection palpable to children seeking asylum when they are in such a storm of movement in their lives, where a "yes" by someone helps them to move on to reconstruction, and a "no" means that that they are either still and watchful, or move into hiding as undocumented children, or move on somewhere where they can call "home".

\section{“Home"}

"Home" as Robert Frost once noted, is "the place where, when you have to go there, they have to take you in" (Frost, 1973). This line, from the poem The Death of a Hired Man, is placed within a broad and sad reflection of the life and circumstances of an itinerant worker. It exemplifies aspects of movement towards a sense of "home", and moreover, a movement that is necessary, perhaps forced. It highlights obligations of the receiver, who at the doorstep, should open up, rather than shut the door. It is, in other words, home as a co-construction. It is dependent on the traveller and the host recognising the ways in which they negotiate over time to generate an experience of being "at home" as a mutual shelter from harm, where reciprocal and safe relationships can be situated, and rituals of daily living practised, allowing confirmation of one's place in the world, and importantly, supporting sustainable evolutions of one's sense of self over time. However, this is in many respects a complicated exchange, not least because gaining a foothold in a new territory means that you have to calibrate losses as well as gains, and "home" is not always, and never has been, a conflict free territory, though bids for peace and continuity can be built within the process of negotiating entry. For refugee children, moving from disaster, carrying complex and paradoxical feelings into new spaces, and needing to remain well behaved in threatening contexts, the challenges are kaleidoscopic, and broad and deep. The meaning of "home" mutates, taking tradition and innovation into account, depending on where they are and who they meet. It is, as Sirriyeh (2013) points, out, this multi-faceted and liquid sense of being at home, which young refugees attempt to find for themselves, wherever their geographical location. For them, home is much more that a lost homeland. It is a chance to manage the debris and reclamation of their lives, so that like tumbleweed, they can regenerate in the right, sustainable conditions. In the same ways that migration itself melts the word "we", the idea of home moves from being solid and fixed to geography and history, to having a contingent, shifting, tidal construction in the present. As such, it is difficult to define its conceptual borders, because they themselves ebb and flow, depending on the nature of home-like constructions between children seeking asylum and their hosts. For children, already saturated with movements, challenges arise of how to feel temporarily at home in contingent spaces, where their sense of entitlement to remain and make a life is curtailed. And the reciprocal question arises for helpers, about how to make a home, through providing containers for such liquid conceptions and experiences. 


\section{The Scottish Guardianship Service}

One example of the co-construction of "home" in such circumstances is the work of the Scottish Guardianship Service that has developed its work across the asylum, welfare and social network domains ${ }^{5}$. In part, it has done so in a context based on the UNCRC inter-locking with Scottish Government policy on seeking to respond to children seeking asylum in humane and humanising ways by prioritising their needs for care. These interlocks are present in considering the UN Committee on the Rights of the Child's thinking in General Comment 6 on the Treatment of Unaccompanied and Separated Children outside Their Country of Origin that notes:

"States are required to create the underlying legal framework and to take necessary measures to secure proper representation of an unaccompanied or separated child's best

interests. Therefore, States should appoint a guardian or adviser as soon as the unaccompanied or separated child is identified and maintain such guardianship arrangements until the child has either reached the age of majority or has permanently left the territory and/or jurisdiction of the State, in compliance with the Convention and other international obligations" (UN Committee on the Rights of the Child, 2005).

While immigration remains a reserved matter within the UK - that is to say that the devolved administrations in Scotland, Northern Ireland and Wales cannot control or legislate separately for immigration matters - for welfare related matters within Scotland, there is evidence of the Scottish Government looking to harmonise laws related to child care, social policies, welfare services, strategies, and practices in line with the UNCRC, laying out the ways that children's rights are protected and promoted in Scotland (Scottish Government, 2012a). One way this has occurred since 2010 is through the implementation of a Guardianship Service for asylum seeking and trafficked children, designed to protect and care for children subject to immigration control in the United Kingdom who have come to Scotland. Within the Scottish context, a Guardian is defined as follows:

"A Guardian is someone who accompanies children and young people when they claim asylum or are trafficked and are cared for by health, education and welfare services. A Guardian will help a child or young person to be actively involved in decisions that affect their life and to get the help they need, when they need it. A Guardian is on the child's side, can explain what is happening to them, will listen to their views and experiences and speak up for them when needed. A Guardian will also help a child or young person to plan their future, whether in the UK or elsewhere" (Crawley and Kohli, 2013: 3).

Within the terms of this definition, a Guardian is by the child's side, and on their side, as they arrive, stay or leave. The work of Guardians emphasises companionability and continuity. Particularly in relation to Article 12 of the UNCRC and children's rights to participate in decisions made about their lives, it highlights the need for clear and consistent communication between children's worlds and those of resource holders and decision makers. It is a role that does not have statutory powers in Scotland, nor carries "parental responsibilities" unlike some

5 This paper gives a brief overview of the work of the Scottish Guardianship Service. The full details of the evaluation of the Service, including methodological approaches, are available via Crawley and Kohli (2013). 
other countries (see Ali et al., 2003; Alikhan and Floor, 2007; Goeman et al., 2011), and arguably lacks the solidity of some other brands of Guardianship in Europe. Guardians in Scotland cannot influence, via legal authority, the decisions made by statutory agencies working with such children. Instead, through negotiation, the development of memoranda of understanding between the Service and decision makers and resource holders, and in building sustainable working relationships, the Guardians are allowed to enter and remain in the territories that the children live within. In this more voluntary form, the Service appears to be fluid, slipping into the gaps between statutory services and providing ways for children to access and benefit by such services. It is important to note that the Guardianship Service is itself time limited, having received funding for an initial three years, and now for a further two years, based on the Scottish Government seeing its value after an extensive evaluation (Crawley and Kohli, 2013). It has, so to speak, limited leave to remain, and like the children it assists, its long-term future is uncertain, with a time horizon getting nearer every day. So in the contingent space generated by funding restrictions and time limits, it does its work, offering protection in a number of ways across each domain.

In the asylum domain this takes the form of Guardians spending time with children to explain rights and entitlements for protection, using clear and simple language, supplemented by diagrams and maps explaining the roles and responsibilities of decision makers. Given the mass of bureaucratic and technical languages, Guardians make sure that children understand asylum processes and outcomes, and that this fits their individual capacities to absorb information. Two key aspects assist with this absorption. Firstly, repetitions of information over time, taking account of the ways the young person's movements from bewilderment to understanding are taking place. Secondly, listening in detail to the "asylum story" within the context of getting to know the young person's bigger biography, where further details of information relevant to the claim might emerge. Sometimes, the young people in the Service simply do not know what is important to tell. So the Guardians make sure that the story has coherence, playing close attention to inconsistencies and inaccuracies in the young person's Statement of Evidence, and bringing this to the attention of legal representatives in order to close gaps and correct information, thus enhancing the possibilities of claims being seen as credible. In the broader context on inter-agency working, the Guardians also ensure that general information about children claiming asylum is understood in terms of its logic and flow, so that professionals assisting young people are themselves less bewildered by what to do with relevant information that they know and can transmit to decision makers. Part of this is to ensure high quality legal representation of the asylum claim, and so Guardians make sure that access to legal representation is prompt and effective, bridging and linking with good lawyers to process individual claims. In some instances, they also attend asylum interviews, at the request of the young person or their allocated social worker, to make sure that the interview is conducted correctly. Ultimately the aim of the Service within the asylum domain is to ensure that decisions made about children are fair, based on as complete a set of information as possible, within the framework of a young person understanding his or her rights within asylum processes, including rights of appeal.

Within the domain of welfare, protection by Guardians is maintained in reference to the Scottish Government's promise to all its children to maintain 
health, well-being and opportunities to grow up safely in Scotland, expressed in policy via Getting it Right for Every Child (GIRFEC) (Scottish Government, 2012b). The outcomes for GIRFEC are expressed as follows:

\section{Figure 3: GIRFEC well-being outcomes}

\begin{tabular}{|l|l|}
\hline Safe & Protected from abuse, neglect or harm \\
\hline Healthy & $\begin{array}{l}\text { Experiencing the highest standards of physical and mental } \\
\text { health, and supported to make healthy, safe choices }\end{array}$ \\
\hline Achieving & $\begin{array}{l}\text { Receiving support and guidance in their learning - boosting } \\
\text { their skills, confidence and self-esteem }\end{array}$ \\
\hline Nurtured & Having a nurturing and stimulating place to live and grow \\
\hline Active & $\begin{array}{l}\text { Having opportunities to take part in a wide range of activities - } \\
\text { helping them to build a fulfilling and happy future }\end{array}$ \\
\hline Respected & $\begin{array}{l}\text { To be given a voice and involved in the decisions that affect } \\
\text { their wellbeing }\end{array}$ \\
\hline Responsible & Taking an active role within their schools and communities \\
\hline Included & $\begin{array}{l}\text { Getting help and guidance to overcome social, educational, } \\
\text { physical and economic inequalities; accepted as full members of } \\
\text { the communities in which they live and learn }\end{array}$ \\
\hline
\end{tabular}

Here, protection focuses on an enduring relational responsibility, linking policy with practice to safeguard children as they grow up, as well as providing the conditions of living that lead to sustainable futures. It is the scaffolding for a sense of "home". Moreover, it moves from being a procedurally tight definition of protection in terms of refugee status and procedural safety, with clearly defined roles for lawyers and asylum decision maker, to one with flexible boundaries around an environment of care and welfare. For Guardians working in the domain of welfare, this looser definition of protection has led to some confusion about the ways their responsibilities intersect with those of social workers allocated to young people seeking asylum. With social workers being the main providers of, or connectors to, health, education and accommodation services within the domain, there has been a tussle at times about who best understands the child, and who therefore is responsible for ensuring that the GIRFEC outcomes are met. In effect, Guardians have had to carefully shape their roles to make sure that as advocates for the child, they balance protection as representation of the child's case, with protection as a consensual responsibility with social work. The co-construction of protection as a shared endeavour has emerged over time, with an extensive commitment by Guardians and social workers to collaborate. This has been possible in part through the detailed exposition of protocols of engagement, identifying how to work best with overlaps and gaps in role and tasks. One young person had this to say, when asked to describe, from his own position, how he saw social works and Guardians offering protection. He said:

"I tell you the difference in my Guardian and my Social Worker. I see my Guardian a lot. I don't see my Social Worker so much. My Guardian is like my mother, and my Social Worker is like my Father. The mother helps you every day and the father, he comes to correct you..." (Crawley and Kohli, 2013: 68).

This view shows two important facets. Firstly, there is the evocation of parents, and a confirmation of the ways young asylum seekers graft previous lives with new ones when thinking about the ways they feel protected. Secondly, 
there is the issue of how time is invested and spent in offering a service, with Guardians able to take time and make time in ways that young people using the service find valuable.

In addition to being available to children in a familial way, Guardians' work in the welfare domain encompasses explaining to children the roles and responsibilities of other professionals. This is particularly important in understanding the structures and processes of formal assistance for children coming from countries where few such systems exist. So Guardians explain these systems, how they link up, what to expect from service providers, and how to maximise the benefits of health, education and accommodation providers. As advocates, they attempt to ensure that other service providers fulfil their obligations to children seeking asylum, and that the quality and standards of service provision are met within the frame delineated by GIRFEC for each child needing assistance. Within their broader responsibilities of making sure that welfare services work together for children seeking asylum, Guardians make sure that effective coordination is present between services, and that any potential gaps are narrowed, to allow young people to be safe and embedded in formal networks of care. So in many respects, the construction and maintenance of formal networks is based on constant movement between, within and alongside other services. Over time, this regenerates part of the protective networks that children seeking asylum require to bring order to their lives.

However, for children seeking asylum, the notion of order in their asylum and welfare domains is not enough. Asylum keeps them alive and welfare keeps them living, but together they do not necessarily bring them back to ordinary life. So the Guardians have also focussed on the ways that the regeneration of social networks of care and support can be used to help children seeking asylum to feel part of a community. They do this in two important ways, both of which are interconnected. Firstly, through creating an office that feels like a home, as a contrast to the Home Office. Here, children seeking asylum can come and go as they please, where they can be a little messy, and where they do not have to be driven by deadlines and prioritise neatness and correctness as they do within formal networks of protection. They know all the Guardians, and the Guardians know them all. Together they celebrate birthdays, go shopping, attend prize giving events at schools and colleges, and generally provide social activities where young people can form communities of experience even though they come from different parts of the world. While appointments are made and met, time is not like a food parcel, given in small portions. Instead, there are opportunities to mix and mingle and be at ease, so that "not serous talking" can happen, as well as the heavy and hard work of remembering the past and worrying about the future. As one Guardian observed, when emphasising the protective nature of such encounters:

"This is a sort of safe space, and the young folk feel relaxed when they walk through the door. Everyone knows them by name, and it's straight away, 'how are you?' If they arrive and you're having lunch, it will be 'sit down, do you want a bit of this lunch', and everyone is fetching plates... You would just not get that environment in a more formal organisation. It's a family context, where they form part of the family. It's not 'people can't see you right now, they're on their lunch break, and if you wait in the waiting area, we'll tell you when they are available" (Crawley and Kohli, 2013: 79). 
This observation generates a humanitarian fluency that is appraised by the children themselves as homely. In one instance a Guardian tells a story of one of her young people coming to the Guardianship Office with a friend. The friend was not part of the Guardianship Service. She observed her young person say to the other:

“Do you want a cup of tea? Did you know I can just open the cupboards here and take biscuits?"

In these instances movement is poignant, not tied to worries about entitlement. Young people can relax, be at ease, and temporarily be "at home". The strong sense of being able to open a cupboard door without permission, and not having to be watchful, provides a momentary glimpse at least, of what life may have been like, or could be like if things go well, and they are allowed to "dissolve into place" (Baumann, 1996) as noted earlier.

Secondly, Guardians ensure that children claiming asylum have structured social activities where they can build alliances with each other, develops their own skills and confidence, and get to know Scotland as a place beyond the borders of their immediate localities. Such activities range from regular group work focussing on making sense of their lives, to photography and craft workshops, and film-making. Visits to the Scottish Parliament to engage with democratic processes are interspersed with T-shirt designing, drumming workshops, and visits to theatres and art galleries. Sometimes the Guardians simply meet in the evenings to play board games with children, to paint country of origin flags, and to consider how they can create artefacts that can be placed in asylum interview rooms to make them more "child-friendly".

So in working across the domains of asylum, welfare and social networks, Guardians have come to be appraised highly by young people themselves as providers of home, even if the home is temporary. In one instance, a young person noted that the Guardians "make us feel that we are human". This is perhaps a key accolade in delivering a humanising service that bridges all the worlds in which they live. Movements to and fro between the domains create interlocks across the big asylum matters and the little kindnesses of everyday life, and make protection a matter not just of life and death, but also of living in sustainable ways. In itself, the meaning of protection for children on the move changes across each domain, as it should if the needs for protection are understood within the terms of the UNCRC - as a shield and an embrace.

\section{Conclusions}

Migration transforms life forever. Its legal, practical and psychological dimensions present newcomers and receivers with threats and opportunities that need to be experienced by them coherently. This is profoundly challenging, and for some at least, an unbearable paradox. It is also a paradox that children seeking asylum endure in multiple ways as they leave their homelands and move across countries, as time passes, and as they grow up and adjust themselves psychologically. Once they are on the move, the past cannot be the future, even if they are returned to the country of origin for settlement. They (and their helpers) also have to work out what protection means, and where it lies, and with whom, at 
different stages of their transits, arrivals, and lifelong settlement. In this paper, I have argued that even in temporary places, children can be protected in an embracing way, so long as the UNCRC, national policies, and local practices interlock, and so long as workers, such as the Guardians in Scotland, work across the domains of asylum, welfare and social networks in ways that generate clarity, continuity and coherence. Here, bridges can be made between memories of the past, and hopes for the future, within a broad and deep understanding of the pitfalls and opportunities that arise in the present. Ultimately, protecting children on the move is about them being able to call somewhere and someone "home", within all its complexity and colour. Protection in that respect is about coming back to ordinary life, and feeling human.

\section{References}

Ali Mehrunnisa, Taraban Svitlana and Gill Jagjeet Kaur (2003) Unaccompanied/ separated children seeking refuge in Ontario: a review of documented policies and practices, CERIS Working Paper No. 27, Toronto, CERIS, 46 p.

Alikhan Sajid and Floor Malika (2007) Guardianship Provision Systems for Unaccompanied and Separated Children in Europe: Initial Mapping, Geneva, UNHCR, $60 \mathrm{p}$.

Anderson Philip (2001) "You Don't Belong Here in Germany...": On the Social Situation of Refugee Children in Germany, Journal of Refugee Studies, 14 (2), pp. 187-199.

Ayotte Wendy (2000) Separated Children Coming To Western Europe. Why they travel and how they arrive, London, Save the Children, $94 \mathrm{p.}$

Bauman Zygmunt (1996) Assimilation into Exile: The Jew As A Polish Writer, Poetics Today, Creativity And Exile: European/American Perspectives II, 17 (4), pp. 569-597.

Bhabha Jacqueline (2006) Not a sack of potatoes: moving and removing children across borders, Boston University Public Interest Law Journal, 15, pp. 197-217.

Bhabha Jacqueline and Finch Nadine (2006) Seeking Asylum Alone: Unaccompanied And Separated Children and Refugee Protection in the UK, Cambridge, John D and Catherine T MacArthur Foundation, 214 p.

Bhatt Sajata (1997) Point No Point, Selected Poems, Manchester, Carcanet Press, $149 \mathrm{p}$.

Bögner Diana, Herlihy Jane and Brewin Chris R. (2007) Impact of sexual violence on disclosure during Home Office interviews, British Journal of Psychiatry, 191, pp. 75-81.

Bolton Syd (2012) Best Interests: Safeguarding and Promoting the Welfare of Children, in Lisa Woodal Ed., Working With Refugee Children: Current Issues In Best Practice, London, Immigration Law Practitioners Association, 178 p.

Brighter Futures (2013) The Cost of Waiting. How waiting in limbo for immigration resolution affects the lives of young asylum seekers and young migrants in the UK, London, Brighter Futures, $20 \mathrm{p}$.

Bronstein Israel and Montgomery Paul (2011) Psychological distress in refugee children: a systematic review, Clinical Child and Family Psychology Review, 14, pp. 44-56. 
Castles Stephen (2013) The Forces Driving Global Migration, Journal of Intercultural Studies, 34 (2), pp. 122-140.

Christiansen Lars Koberg and Foighel Nina (1990) Trauma Treatment for Unaccompanied Minor Refugees. Experience from the Work in OASIS in Copenhagen, in Helga Jockenhövel-Schiecke Ed., Unaccompanied Refugee Children in Europe: Experience with Protection, Placement and Education, Frankfurt, International Social Service, German Branch, pp. 150-160.

Coenders Marcel, Lubbers Marcel and Scheepers Peer (2013) Resistance to immigrants and asylum seekers in the European Union, in Gary P. Freeman, Randall Hansen and David L. Leal Eds., Immigration and Public Opinion in Liberal Democracies, New York, Routledge, 402 p.

Coole Caroline (2002) A warm welcome? Scottish and UK media reporting of an asylum seeker murder, Media, Culture and Society, 24, pp. 839-852.

COSTI Immigrant Services and UNHCR (2011) A Book of Poems, Expressions from Our Youth, Toronto, $40 \mathrm{p}$.

Crawley Heaven (2010) Chance of choice. Understanding why asylum seekers come to the UK, London, Refugee Council, $58 \mathrm{p}$.

Crawley Heaven and Kohli Ravi KS (2013) She endures with me. An evaluation of the Scottish Guardianship Service Pilot, [online] last checked on 18/10/2013. URL: http://www.scottishrefugeecouncil.org.uk/assets/6798/ Final_Report_2108.pdf

Franks Myfanwy (2006) Count Us In: Young Refugees in the Education System, London, The Children's Society, $22 \mathrm{p}$.

Frost Robert (1973) Robert Frost: Selected Poems, Penguin, Harmondsworth, Middlesex, $144 \mathrm{p}$.

Goeman Martine, Van Os Carla, Bellander Eva, Fournier Katja, Gallizia Gabriela, Arnold Samantha, Gittrich Thomas, Neufeld Inger and Uzelac Marina (2011) Core Standards for Guardians of Separated Children in Europe. Goals for Guardians and Authorities, Leiden, Defence for Children-ECPATThe Netherlands, 74 p.

Goodwin-Gill Guy (2012) Introduction: Expert roundtable discussion on “The United Nations Convention on the Rights of the Child and its application to child refugee status determination and asylum processes", Journal of Immigration Asylum and Nationality Law, 26, pp. 226-231.

Goodwin-Gill Guy (1995) Unaccompanied refugee minors. The role and place of international law in the pursuit of durable solutions, The International Journal of Children's Rights, 3, pp. 405-416.

Herlihy Jane, Scragg Peter and Turner Stuart (2002) Discrepancies in autobiographical memories - implications for the assessment of asylum seekers: repeated interviews study, British Medical Journal, 324, pp. 324-327.

Kirkpatrick Betty (1992) Brewer's Concise Dictionary of Phrase \& Fable, Oxford, Cassell, 1136 p.

Kohli Ravi KS (2007) Social work with unaccompanied asylum seeking children, Basingstoke, Palgrave Macmillan, 240 p.

Kohli Ravi KS and Connolly Helen (2009) Young People Seeking Asylum, in Alison Petch Ed., Managing Transition: support for individuals at key points of change, Policy Press, pp. 73-92. 
Kohli Ravi KS and Mather Rosie (2003) Promoting psychosocial well-being in unaccompanied asylum seeking young people in the UK, Child \& Family Social Work, 8 (3), pp. 201-212.

Kvittingen Anna Verley (2010) Negotiating childhood: Age assessment in the UK asylum system, Working Paper 67 Refugee Studies Center, Oxford, 58 p.

Louis Winnifred R., Duck Julie M., Terry Deborah J., Schuller Regina A. and Lalonde Richard N. (2006) Why do Citizens want to keep refugees out? Threats, fairness, and hostile norms in the treatment of asylum seekers, European Journal of Social Psychology, 37 (1), pp. 53-73.

Melzak Sheila (1995) Refugee children in exile in Europe in Judith Trowell and Marion Bower Eds., The emotional needs of young children and their families. Using psychoanalytic ideas in the community, London, Routledge, pp. 256-263.

Mougne Christine (2010) Trees Only Move InThe Wind: A Study of Unaccompanied Afghan Children in Europe, United Nations High Commissioner for Refugees, [online] last checked on 22/02/2014. URL: http://www.unhcr.org/4c1229669.html

Nin Anais (1971) The Diary of Anais Nin, volume four: 1944-1947, Gunther Stuhlmann Ed., New York, Houghton Mifflin Harcourt, 235 p.

Ni Raghallaigh Muireann and Gilligan Robbie (2010) Active survival in the lives of unaccompanied minors: coping strategies, resilience, and the relevance of religion, Child and Family Social Work, 15 (2), pp. 226-237.

Ojalehto Bethany and Wang Qi (2008) Children's spiritual development in forced displacement: a human rights perspective, International Journal of Children's Spirituality, 13 (2), pp. 129-143.

Papadopoulos Renos (2010) Identifying Psychosocial Vulnerabilities. The Asylum Seeker's Protection Index (ASPI), [online] last checked on 18/10/2013. URL: http:// www.evasp.eu/Renos\%20Papadopoulos\%20Rome2010.pdf

Pobjoy Jason (2013) A child rights framework for assessing the status of refugee children, in Satvinder Singh Juss and Colin Harvey Eds., Contemporary Issues in Refugee Law, London-Belfast, Edward Elgar, pp. 91-138.

Refugee Studies Centre (2013) The deportation of unaccompanied minors from the EU. Family tracing and government accountability in the European Return Platform for Unaccompanied Minors (ERPUM) project, Workshop report, 3 May 2013, Oxford, Refugee Studies Centre, 31 p.

Rigby Paul and Whyte Bill (2013) Children's Narrative within a Multi-Centred, Dynamic Ecological Framework of Assessment and Planning for ChildTrafficking, British Journal of Social Work, [online]. DOI: 10.1093/bjsw/bct105

Robinson Vaughan and Segrott Jeremy (2002) Understanding the decision making of asylum seekers, London, Research, Development and Statistics Directorate, Home Office, $74 \mathrm{p}$.

Scottish Government (2012a) Do the Right Thing, Progress Report 2012, Edinburgh, Scottish Government, 64 p.

Scottish Government (2012b) A Guide to Getting it Right for Every Child, Edinburgh, Scottish Government, $31 \mathrm{p}$. 
Senovilla Hernández Daniel (2013) Unaccompanied Children Lacking Protection in Europe. Final Comparative Report, [online] last checked on 22/02/2014. URL: http://www.mshs.univ-poitiers.fr/migrinter/PUCAFREU/PUCAFREU\%20comparative\%20report\%20EN.pdf

Sigona Nando and Hughes Vanessa (2012) No way out, no way in. Irregular migrant children and families in the UK, COMPAS, Oxford, University of Oxford, $46 \mathrm{p}$.

Sirriyeh Ala (2013) Inhabiting Borders, Routes Home, Farnham, Ashgate Publishing, $215 \mathrm{p}$.

Sporton Deborah and Valentine Gill (2007) Identities on the move: the integration experiences of Somali refugee and asylum seeker young people, University of Leeds \& University of Sheffield, 20 p.

UNHCR (2013a) Displacement. The new 21 ${ }^{\text {st }}$ century challenge. UNHCR Global Trends, Geneva, UNHCR, $47 \mathrm{p}$.

UNHCR (2013b) Beyond Proof. Credibility Assessment in EU Asylum Systems, Brussels, UNHCR, 286 p.

UN Committee on the Rights of the Child (2013) General comment No. 14 on the right of the child to have his or her best interests taken as a primary consideration (art. 3, para. 1), Geneva, UNCRC, 21 p.

UN Committee on the Rights of the Child (2005) General Comment No. 6 on the Treatment of Unaccompanied And Separated Children outside their country of Origin, Geneva, UNCRC, 25 p.

Urry John (2007) Mobilities, Cambridge, Polity Press, 334 p.

Vertovec Steven (2007) New Complexities Of Cohesion In Britain: Super-Diversity, Transnationalism and Civil-Integration, Wetherby, Commission on Integration and Cohesion, Communities and Local Government Publications, 40 p.

Wade Jim, Mitchell Fiona and Baylis Graeme (2005) Unaccompanied asylum seeking children. The response of social work services, London, British Association for Adoption and Fostering (BAAF), 248 p.

Wade Jim, Sirriyeh Ala, Kohli Ravi KS and Simmonds John (2012) Fostering unaccompanied asylum seeking young people: creating a family life across a world of difference, London, BAAF, $331 \mathrm{p}$.

Wong (2009) Time: Concepts and Trends - How Attitudes, Personal Choices, Cultural Norms and Public Policies Impact on Relationships and Wellbeing, Cambridge, Relationships Foundation, $160 \mathrm{p}$. 


\section{Ravi Kohli}

\section{Protecting Asylum Seeking Children on the Move}

This paper considers the ways that children seeking asylum can be assisted to make sense of movement in their lives as forced migrants, and to find a sense of "home" in a foreign country after arrival, even if their stay in that country is temporary. It explores the proposition that movement happens in three dimensions - as geographical displacement, as the passage of time, and as psychological and maturational change. While acknowledging the utility of using the 1951 Refugee Convention as a defence against children's persecution, the paper suggests that the 1989 UN Convention on the Rights of the Child offers a wider framework for considering asylum seeking children's life-long well-being. Within the UNCRC's design, an example of a Guardianship service in Scotland is used to track movement across three domains of practice - when processing an asylum claim, providing welfare, and regenerating social networks. The paper considers that offering protection is not just a shield against persecution, but also an embrace that makes children feel "at home".

\section{.. La protection des mineurs migrants non accompagnés demandeurs d'asile}

L'article examine les différentes formes d'assistance offertes aux enfants demandeurs d'asile afin de donner un sens à leur expérience de migration forcée et de faciliter leur accueil dans un pays étranger, même si leur séjour est temporaire. L'auteur avance l'idée que le mouvement a lieu en trois dimensions : le déplacement géographique, le passage du temps et le changement de maturité psychologique. Tout en reconnaissant I'utilité de la Convention relative au statut des Réfugiés de 1951, il suggère que la Convention des Nations Unies de 1989, relative aux droits de l'enfant (CIDE), offre un cadre plus large pour garantir le bien-être des mineurs isolés demandeurs d'asile. Dans le cadre de la CIDE, l'exemple du Service deTutelles en Écosse est utilisé pour analyser la mobilité des mineurs à partir de trois types de pratiques administratives : le traitement d'une demande d'asile, la construction d'un projet éducatif et la reconstitution de réseaux sociaux. L'auteur considère que la protection offerte à ces mineurs ne doit pas seulement être un bouclier contre la persécution, mais aussi une opportunité de se sentir " chez eux"

\section{Proteger a los menores solicitantes de asilo en situación de migración independiente}

El artículo examina las formas de asistir a los menores solicitantes de asilo a fin de dar sentido a su vida como migrantes forzosos así como para facilitar que se sientan acogidos en un país extranjero, e independientemente de que su estancia sea temporal. El artículo se basa en la idea de que el movimiento tiene lugar en tres dimensiones - como desplazamiento geográfico, como paso del tiempo, como cambio psicológico y evolución hacia la madurez. Aún reconociendo la validez de la Convención de 1951 relativa al estatuto de los refugiados, el artículo considera que la Convención de 1989 de Naciones Unidas relativa a los Derechos del Niño aporta un marco más completo para garantizar el bienestar a largo plazo de los menores solicitantes de asilo. Dentro del marco protector de la Convención, se utiliza el ejemplo del Servicio deTutelas en Escocia para analizar la movilidad a partir de tres tipos de prácticas administrativas: el tratamiento de la solicitud de asilo, la edificación de un proyecto educativo y la reconstitución de las redes sociales de los menores. El documento considera que la protección debe operar no solamente como un escudo contra toda forma de persecución, sino sobre todo como una oportunidad de que los menores se sientan como en su propio hogar. 